\title{
The Use of Idiomatic Language as a Strategy for Receptor-Oriented Translation: A Study on Tomris Uyar's Rendering of Flannery O'Connor's Grotesque Stories: “The Lame Shall Enter First" and "The Comforts of Home"
}

Bülent Akat ${ }^{1}$, Tuba Kümbül2*

${ }^{1}$ Department of Translation and Interpreting Studies, Çankaya University, Ankara/Turkey

${ }^{2}$ Department of Common Courses (English Unit), Hitit University, Çorum/Turkey

Corresponding Author: Tuba KÜMBÜL, E-mail: tubakumbul@gmail.com

\section{ARTICLE INFO}

Article history

Received: September 01, 2018

Accepted: October 15, 2018

Published: October 31, 2018

Volume: 6 Issue: 4

Conflicts of interest: None

Funding: None

\section{Keywords:}

Receptor-oriented Translation,

Dynamic Equivalence,

Eugene A. Nida Grotesque,

Colloquial Language,

Idiom

\begin{abstract}
This study is concerned with an analysis of Tomris Uyar's rendering of two grotesque stories by the American fiction writer Flannery O'Connor, "The Lame Shall Enter First" and "The Comforts of Home", translated into Turkish as "Önce Sakatlar Girecek" and "Yuvanın Nimetleri" respectively. The article mainly focuses on the translator's use of idiomatic language in the rendering of these grotesque stories as a strategy for conveying the semantic content of the stories to the receptor audience as well as for evoking in them the feelings and responses similar to those created in the source-text reader. In her translations, Tomris Uyar adopts a receptororiented strategy closely associated with Eugene A. Nida's concept of Dynamic Equivalence. Out of a desire to achieve an easy, natural, and fluent style in translation, the translator relies heavily on the use of idioms in receptor language, thus creating in the reader the feeling that these stories were originally written in Turkish.
\end{abstract}

\section{INTRODUCTION}

\section{Various Approaches to the Concept of Equivalence in a Historical Perspective}

Throughout history, there has been an ongoing debate among translation scholars about the dichotomy between source-oriented and target-oriented translation. Translation theorists have been concerned particularly with the question of how equivalence between the source text and target text can best be achieved. Some scholars favored a source-oriented, hence a word-for-word (literal) translation while others advocated a target-oriented, that is, a sense-for-sense (free) translation. Undoubtedly, there are other modes of translation between these diametrically opposed positions (Pym, 2010, p.32).

Discussions about the two poles of translation stated above date as far back as the scholars of the Roman period, among them Cicero, who argued that one should translate freely; that is, in a manner that sounds "natural" in the target language. In other words, Cicero preferred the method of domestication (ibid., p.30-31). Like Cicero, the Roman poet Horace advocated the method of sense-for-sense translation. In Ars Poetica, Horace clearly stated that his ultimate purpose in translation was to fashion "an aesthetically pleasing and creative text in the TL" (Munday, 2008, p.20) Another prominent figure in the Roman writing tradition, St.Jerome set himself firmly against word-for-word translation, rendering original texts with the idea that sticking so closely to the source text would result in an "absurd translation" and fail to communicate the sense of the original work. The sensefor-sense method of translation, by contrast, would enable the translator to effectively create in the target language both the sense and content of the source text (ibid., p.20). Similarly, the Dutch philosopher Desiderius Erasmus adopted a target-oriented approach in translation. In his renderings of The Bible, Erasmus aimed to make the source language as accessible to target-text readers as possible through the use of a language that sounds familiar to them (Bassnett, 2002, p.75). According to Erasmus, one of the criteria for a good translation was the employment of idioms widely available in target language, an idea reflecting his conviction that it is the rendering of meanings, rather than of words, which matters (De Jonge, 2016, p.29). Another notable translation scholar in the history of European writing is Martin Luther, the major figure of the Protestant Reformation who rendered The New Testament and The Old Testament into German. Like his predecessors Cicero, Horace and St. Jerome, Luther 
opposed the strategy of word-for-word rendering on the grounds that it would fail to convey the same meaning and effect created by the original text, and could even become almost incomprehensible. Instead, Luther preferred to use the language of ordinary people, an idiomatic language in particular, which, he believed, would better serve to communicate the feelings involved in the original work (Munday, 2008, p.23-24).

In the Renaissance period, the French translator, Étienne Dolet translated the Bible into his own language, but he was executed for having distorted the ideas in The Bible (Munday, 2008, p.23). In his study entitled The Way of Translating Well from One Language into Another, Étienne Dolet argued that one must avoid word-for-word renderings, an idea suggestive of his inclination toward sense-for-sense translation (Bassnett, 2002, p.61).

In the seventeenth-century England, translators such as Ben Jonson, Abraham Cowley and John Dryden came up with different approaches to the concept of equivalence in translation. Ben Jonson was in favor of a 'word-for-word' and 'line-by-line' translation, which he believed was the best way to achieve maximum faithfulness to the source text. Abraham Cowley, on the other hand, advocated a very free form of translation that stood at the other end of the continuum. According to Cowley, the loss of beauty that inevitably occurred in translation had to be somehow balanced by the use of "wit or invention" (Munday, 2008, p.26), the most effective strategy for creating an equally aesthetic work. John Dryden, the leading literary figure of the Restoration Period in England, took a midway position between these two poles. Calling Jonson "a verbal copier" (ibid., p.26) and coining the term 'metaphrase' for this strategy, Dryden regarded this approach as an extreme form of word-for-word translation. Again, Dryden rejected Cowley's "very free" (ibid., p.26) form of translation on the grounds that it verged on an act of irreverence "to the memory and reputation of the dead" (ibid., p.26). The method of translation Dryden preferred was 'paraphrase', a term that he coined as a synonym for sense-for-sense translation. Again in the same century, the English scholar Sir John Denham wrote in favor of a free style of translation. Denham rejected the method of literal translation because he believed that priority was to be given to conveying the spirit of the original work to the target audience.

In the late eighteenth century, the Scottish translation scholar Alexander Fraser Tytler, best known for his seminal work Essay on the Principles of Translation, called attention to the importance of creating equivalent effect on the target reader. According to Tytler, the primary goal of a good translation was to transfer the main idea of the source text to target-text readers in such a way that they could clearly understand the message. Equally important, he argued, was the translator's ability to arouse the same feelings and impressions as those created by the author of the original text in the source text reader (ibid., p.27).

In the early nineteenth century, the German translation scholar Friedrich Schleiermacher wrote his famous essay $O n$ the Different Methods of Translating, in which he elaborat- ed on the strategy of foreignization (ibid., p.28). In the essay, Schleiermacher called attention to the importance of bringing the target text reader closer to the source text. He believed this strategy was instrumental in ensuring that the content and effect of the original text would be communicated to the target text reader in the best way possible. Favoring an 'alienating' rather than 'naturalizing' approach in translation, Schleiermacher dismissed the other alternative -moving the source text writer toward the target text reader- simply because he believed this strategy could neither convey the content of the original work nor create an effect on the target-text reader similar to the one created by the original text (ibid., p.29). In the nineteenth century England, the debate as to whether the translator should stand closer to the source language or target language found an echo in the controversy between Francis Newman and Matthew Arnold over the translation of Homer. In his English version of Homer's Ili$a d$, Francis Newman adopted a foreignizing approach manifested in his faithful and literal translation of this famous work (Kristal, 2002, pp.18-19). By contrast, Matthew Arnold, in his famous work On Translating Homer, argued that the use of modern English would be more appropriate for the translation of Homer's work; hence he preferred the method of domestication (Venuti 2001, p.243).

In the twentieth century, preoccupation with the basic division between source-oriented and target-oriented translation gained a new dimension with the growing interest of some scholars in the concept of equivalence, linguistic equivalence in particular. Among them was the English translation critic Peter Newmark who, in his oft-quoted book Approaches to Translation, distinguished between two types of translation: "semantic" and "communicative" (as cited in Munday, 2008, p.44). In semantic translation, decisions made in the process of translation are influenced by the overriding presence and authority of the source-text author, which leads the translator to remain as much faithful to the original work as possible (Palumbo, 2009, p.167). Communicative translation, on the other hand, is characterized by an awareness of and readiness for meeting the target reader's expectations as much as possible.

The dichotomy between source-oriented and target-oriented translation found reflection also in the work of another translation scholar, the Czech theorist Jiri Levy (2011), whose seminal work The Art of Translation is often cited due to the basic distinction the author drew between two types of translations; "illusory" and "anti-illusory". In anti-illusory translation, the reader is aware of the fact that the text he/ she is reading is a translation because the translated work reflects the semantic, syntactic, and lexical features of the source text (p.20). In illusory translation, on the other hand, the reader can hardly feel that what he/she is reading is a translation because the text has been effectively adapted to the target language and culture (Pym, 2010, p.32). Of these two types of translations, Levy preferred illusory translation.

The German linguist and translation scholar Juliane House (2015), in her oft-cited work Translation Quality Assessment, introduced two types of translations: 'Overt translation' and 'Covert translation' (p.23). In overt translation, 
the linguistic and cultural features of the source text are carefully retained in the translated work (House, 2002, p.98). By contrast, in covert translation it is hard for target readers to know if the text they are reading is really a translation (ibid., pp.89-90). Another German translation scholar, Christiane Nord, best known for her seminal work Text Analysis in Translation, distinguished between two types of translation: Documentary and Instrumental. In the first type of translation, the translated work functions "as an explicit representation of the previous text," therefore as a document (Pym, 2010, p.32). Instrumental translation, on the other hand, is a form of communication that is independent of the source text (Santos and Miguel, 2016, p.76). In this kind of translation, the aim is to convey the source-text message to the target culture in such a way that readers will not feel that it is a translation (Munday, 2008, p.82).

The Israeli scholar Gideon Toury (as cited in Pym, 2010, p.84), in his widely-cited work, In Search of a Theory of Translation, favored a receptor-centered approach suggested by his argument that "translations should be regarded as facts of target cultures". Of special interest in the book is Toury's concept of initial norms, which concerns the critical choice to be made by translators at the beginning of the process as to whether they will commit themselves to the norms of the source language and culture or to those of the target language and culture. In the former case, the translated text is called 'adequate', in the latter 'acceptable' (Munday, 2008, p.112).

The American translation theorist Lawrence Venuti, the author of a highly influential book, The Translator's Invisibility, is known for the distinction he made between two categories of translation: "resistant" and "fluent". Writing about the latter in a disapproving manner, Venuti criticized the reviewers who preferred fluent translations written in modern, general, standard English that is natural and idiomatic. He argued that such domesticating strategies reduce the translator's role to a level where s/he becomes almost invisible, which is not a good thing in itself (Munday, 2008, pp.154-5). Instead, Venuti insisted that the translator be visible; hence, he favored the strategy of resistant translation (foreignization), which involves rendering a work in such a way that the linguistic, stylistic, and cultural elements of the original text are preserved to the maximum extent possible (ibid., p.183-4).

Apart from the scholars cited above, many other theorists have voiced their opinions on the basic dichotomy between source-oriented and target-oriented translation, among them the American translation scholar Eugene A. Nida, who holds an important place in the field with his two seminal works Toward a Science of Translating and The Theory and Practice of Translation (Nida \& Taber). For the purposes of this article, Nida has been singled out for special consideration particularly due to the receptor-oriented approach embodied in his notion of dynamic equivalence. In this article, two grotesque stories by Flannery O'Connor rendered into Turkish by Tomris Uyar "Önce Sakatlar Girecek" and "Yuvanın Nimetleri" will be analyzed on the basis of Nida's translation theory in general, and his concept of dynamic equivalence in particular. Specifically, an attempt will be made to draw parallels between the key principles of dynamic equivalence and the translations concerned, especially in terms of the translator's tendency to follow a receptor-centered approach in the rendering of grotesque stories, and her unmistakable tendency toward employing idioms in the process. Hence, before going into a detailed analyis of the translations themselves, it will be useful to offer some insight into Nida's views on translation theory.

\section{EUGENE A. NIDA'S NOTION OF DYNAMIC EQUIVALENCE: A RECEPTOR-ORIENTED TRANSLATION STRATEGY}

Among the scholars whose theories contributed to the evolution of translation into an independent discipline, Eugene A. Nida holds a prominent position. In fact, Nida's theoretical work had largely predominated the field of translation studies well until 1980s when new approaches bringing functional, cultural, historical, and descriptive dimensions to the discipline began to appear (Palumbo, 2009, p.169). Nida's unique contribution to the field of translation studies lies in the originality of the ideas he introduced on the linguistic, communicative, and contextual aspects of translation, as well as in his notion of dynamic equivalence which forms the basis of his receptor-centered approach (ibid., p.169).

In his often-quoted work Toward a Science of Translating, Nida mentions two types of equivalence: 'formal equivalence' and 'dynamic equivalence'. In the book, the former is defined as a type of translation centered on source language and culture while the latter is presented basically as a receptor-oriented strategy that gives priority to the norms of target language and culture. Of the two kinds of equivalence, Nida prefers the latter, for he is fully convinced that the notion of dynamic equivalence proves much more effective in transmitting the message and spirit of the original text to receptor audience. Underlying his preference for the strategy of dynamic equivalence are the remarkable benefits of following this strategy, each of which will be discussed in detail below. Yet, before starting out a full-length discussion on the concept of dynamic equivalence, one should first gain some insight into Nida's notion of formal equivalence, its polar opposite, which will help account for his preference for the former.

\section{Formal Equivalence}

Nida's concept of formal equivalence presupposes a strong adherence to the lexical and grammatical structures of the source language as well as to the elements of the source culture. As Nida (1964) put it, "Such a formal equivalence translation is basically source-oriented; that is, it is designed to reveal as much as possible the form and content of the original message" (p.165). Commenting on the implications of formal equivalence, Nida suggests that in this type of translation "the message in the receptor culture is constantly compared with the message in the source culture to determine the standards of "accuracy" and "correctness" (ibid., p.159). Furthermore, Nida (1964) points out that in such a 
translation one is concerned with such correspondences as poetry to poetry, sentence to sentence, and concept to concept. Viewed from this formal orientation, one is concerned that the message in the receptor language should match as closely as possible the different elements in the source language (ibid., p.159).

After elaborating on the basic implications of formal equivalence, Nida underlines the major problem inherent in this type of translation; namely, it sacrifices the two major components of an effective translation: naturalness and readability (ibid., p.165). Moreover, the tendency to reproduce the source text as faithfully as possible, often manifested in the effort to achieve equivalence even at the level of word or phrase, may detract from the overall effect of the translated work.

\section{Nida's Work on Bible Translating and its Implications}

Nida is mostly known for his translation of the Bible into many languages spoken in different parts of the world. He knew more than eight languages and travelled across the world to get indigenous poeple involved in his efforts to translate the Bible. Over the course of this long process, Nida tried to gain full insight into the language and culture of the natives, gathering a large number of vocabulary and phrases from those people, and then using them in his translations of the Bible. The experiences Nida gained during Bible translation led him to conclude that a receptor-oriented approach based on the principle of dynamic equivalence proved to be the most effective strategy to convey the essential message and spirit of the Bible. To him, it was more important for the translator to help readers accurately comprehend the Bible than to use a poetic language that appeals to their feelings, but fails to make them understand the message. Thus, in translating the Bible into different languages, instead of making literal translations, Nida implemented the strategy of dynamic equivalence to make sure that the semantic content of the original text could be accurately communicated to the receptors of the translated text in terms of the norms of their own language and culture. Convinced that language cannot be dissociated from culture, Nida said "You can't translate without cultural context". Accordingly, when rendering the stories narrated in the Bible, he preferred to follow a strategy that combined the elements of native culture with the dynamism of idiomatic language (The Reverend Eugene Nida, 2018).

As Nida (1964) himself pointed out in Toward a Science of Translating, what he wanted to do in the book was to apply the knowledge and experience he gained during the process of Bible translating to "the wider activity of translating in general" (p.ix). One of the major conclusions he had drawn from this arduous process was that, for the rendering of any kind of text, a receptor-oriented approach aimed at achieving dynamic equivalence was the best way to create equivalent effect and equivalent response on the receptors of the target language. In the same book, Nida cited a few examples about Bible translating in order to illustrate the importance of implementing the concept of dynamic equivalence in the process. For instance, when translating the word "repentance", a translator could use the phrase "to change one's mind about sin" as an equivalent for the original word. In this situation, the average reader would probably have no difficulty understanding the message. But, for the natives of a town in Africa this is not the case. Based on their customs and habits, local people may have a different way of communicating the meaning of the word repentance; so, in this particular situation it might be more appropriate to use the idiomatic expression "spit on the ground in front of" (as in Shilluk, a local language spoken by the indigenous people in the Sudan). In this case, the translator must be aware of the existence of this idiom in Shilluk and employ this idiomatic phrase when rendering the word repentance into the language of the natives (ibid., p.158).

In Toward a Science of Translating, Nida cites another example to show how important it is to take into consideration the linguistic and semantic features of the receptor language. He points out that the translator must be well aware of the idiomatic expressions indigenous people commonly use in their daily lives, and employ them wherever they are found to be fit for the context. As Nida (1964) puts it, when translating the Biblical expression "white as snow" into the language of the natives, it might be more appropriate to use the metaphorical phrase "white as egret feathers" instead of "white as snow" for two reasons: The indigenous people have never seen snow in their lives, and traditionally they associate anything white with egret feathers (pp.157-8). Both examples account for why Nida attached so much importance to the dynamic aspect of language, with special focus on its semantic implications. According to him, one can never ignore the cultural, communicative and contextual overtones of language simply because, in essence, language is a means of communication designed to convey a certain message rather than a mere combination of words coded in a mechanical way. As Nida (1964) put it, "the total amount of information received by a receptor may be quite different from what was intended by a source, and therefore the translator must be concerned with language not only as a code, but also as a communicative event" (p.8).

\section{Dynamic Equivalence}

The cornerstone of Nida's translation theory is the notion of dynamic equivalence, which focuses on finding out "the closest natural equivalent to the source-language message" (Nida, 1964, p.166). In this type of equivalence, the translator tries to make sure that the message is in total agreement with the receptor's linguistic needs and cultural expectations (Munday, 2008, p.42). Nida (1964) argues that this strategy enables the translator to achieve "complete naturalness of expression" (p.159). Dynamic equivalence is a strategy of translation which aims to communicate the meaning of the original text in such a way that the translated text will create the same effect on the target-text audience as the language of the original text did upon the source-text audience. The basic features of this kind of equivalence are an easy and natural style, a marked emphasis on creating a similar response (an equivalent effect), and the precedence of content over form. This type of equivalence presupposes that the words 
and phrases used in the translated text fit the norms of receptor language and culture in order to make the messages more comprehensible and natural to target language receptors. For instance, if the proverb The grass is always greener on the other side of the fence were rendered into Turkish as Çitin diğer tarafindaki çimen her zaman daha yeşildir, the translation would barely convey the meaning of the original statement to target-text readers. Actually, it would be more appropriate to translate this sentence as Komşunun tavuğu komşuya kaz görünür, the exact proverbial (idiomatic) equivalent of the above statement in the target language. In this situation, the use of the Turkish proverb would be especially relevant in that it sounds quite familiar, natural and intelligible to the target audience.

\section{Naturalness of expression}

Underlying Nida's concept of dynamic equivalence is the principle of 'Naturalness'. A strategy of translation based on the notion of dynamic equivalence gives priority to "equivalence of response" over "equivalence of form". Nida (1964) suggests that there are three levels of communication involved in a natural translation: (1) transferring the message in the source language to the receptor language and culture in such a way that it fits the latter; (2) properly conveying the context of the particular message in the original text to the receptor audience; (3) considering the nature of the receptor-language audience (pp.166-7). Commitment to the notion of dynamic equivalence presupposes a certain degree of independence from the source text, which will ensure a natural translation and a higher level of readability (Shakernia, 2013, p.2). Commenting on this issue, the American poet Ezra Pound (as cited in Nida 1964, p.168). contends that, in order to produce a natural translation, the translator has to deal with problems such as "gross grammatical and lexical features" as well as "intonation and sentence rhythm". Stressing the importance of the latter, Paul T. Manchester says, "Fettered to mere words, the translator loses the spirit of the original author" (ibid., p.168). According to Nida, a major factor that may interfere with naturalness is the translator's tendency to use long and complicated sentences when translating "a relatively straightforward" message in the original work (ibid., p.169). Some translators are extremely keen on clarifying a source-text message in order to avoid ambiguities in expression. However, by so doing, they often make the mistake of translating a clear and direct message in the source language in such a way that the translation sounds, as Nida puts it, like "a complicated legal document in the receptor language". This inevitably leads to the loss of "the grace and naturalness of the original" (Venuti, 2000, p.138).

As far as Nida's concept of dynamic equivalence is concerned, the phrase 'naturalness of expression' is also associated with the strategies of fluency and domestication. Nida attaches great importance to the translator's responsibility to translate the source text in such a way that receptors of the target language can fully understand the original message. Furthermore, messages given in translation must be rendered relevant to the language and culture of the receptor audience. To quote Nida, "The translator must be a person who can draw aside the curtains of linguistic and cultural differences so that people may see clearly the relevance of the original message" (Weissbort and Eysteinsson, 2006, p.553). One major way of achieving this goal is to make the features of the source language "recognizable" to the target text reader. In other words, the translator must try to make the original message accessible to the target-text audience by replacing the features of source language and culture with those of the target language and culture. Nida also believes that dynamic equivalence ensures accuracy in translation by creating equivalent effect in the receptor language and culture (ibid., p.553).

\section{Similar response}

Nida's translation theory is marked by a strong emphasis on the linguistic as well as communicative aspects of translation, with special focus on "the reception of target readers" (Palumbo, 2009, p.169). In fact, Nida prefers to use the expression "receptor language" instead of "target language" to draw attention to the fact that translation is all about readers of the receptor language "receiving" a given message, rather than a certain message being "'shot' at a target" (ibid., p.169). Nida holds the view that formal correspondence should be subordinated to dynamic equivalence if appropriate response is to be created in the receptors of the target language (Kuhiwczak and Littau, 2007, p.51).

While Nida attaches special importance to using a "natural' style in translation, he acknowledges that it is rather difficult to produce a translation written with "an easy and natural style", particularly if the original work is one of high quality. He argues that it would be advisable to employ this kind of style in translating if one aims to create in the receptor audience a response similar to that of the receptors of the original work. In Toward a Science of Translating, Nida makes references to a number of scholars who emphasize the importance of creating similar response in translation. Among them is Matthew Arnold (as cited in Nida, 1964, p.164) who stated that: "A translation should affect us in the same way as the original may be supposed to have affected its first hearers". Again, Nida refers to the British translation scholar Benjamin Jowett (1891) who called attention to the importance of producing "similar response" when he said: "an English translation ought to be idiomatic and interesting, not only to the scholar, but to the learned reader. The translator ... seeks to produce on his reader an impression similar or nearly similar to that produced by the original" (ibid., p.164). Writing in the same vein, the Scottish biblical scholar Alexander Souter (ibid., p.164) contended that: "Our ideal in translation is to produce on the minds of our readers as nearly as possible the same effect as was produced by the original on its readers". Still, to the same effect, the translator of the Latin Bible R. A. Knox pointed out that a translation should be "read with the same interest and enjoyment which a reading of the original would have afforded" (ibid., p.164).

\section{Creating equivalent effect}

Commenting on the implications of dynamic equivalence, Nida (1964) maintains that this strategy is based on "the 
principle of equivalent effect," in which "the relationship between receptor and message should be substantially the same as that which existed between the original receptor and the message" (p.159). According to Nida, the success of a translation depends on the extent to which the principles of dynamic equivalence are put into effect. Viewed from this perspective, a successful translation is one which fulfills four main criteria: "(1) making sense, (2) conveying the spirit and manner of the original, (3) having a natural and easy form of expression and (4) producing a similar response" (Palumbo, 2009, p.172).

\section{Form and content}

Regarding the traditional debate over the precedence of form or content in translation, Nida (as cited in Munday 2008, p. 43) argues that content should have priority over form: "Correspondence in meaning must have priority over correspondence in style" if equivalent effect is to be achieved. Nida (1964) maintains that translators who are committed to the concept of formal equivalence are more likely to "distort the message" than those who adopt the principle of dynamic equivalence, and that the latter tend to preserve "more fully and satisfactorily the meaning of the original text" (p.192). Nida and Taber (1982) point out that, in translating a given message from one language to another, the content must be preserved at all costs while "the form, except in special cases, such as poetry, is largely secondary" (p.105). The two theorists further argue that it would be an ideal situation if it were possible to communicate the same content in the receptor language in a form similar to that of the source text. In fact, one should try to maintain the form of the original work as much as possible. However, in cases where the content has priority over the form, it might be necessary to make some changes in the form of the original work to preserve the content. At this point, Nida and Taber caution the translator who, out of a desire to achieve a maximum degree of faithfulness to the source text, tends to refrain from making any changes in the form of the original text. They claim that "an excessive effort to preserve the form inevitably results in a serious loss or distortion of message" (pp.105-6).

\section{THE ORIGIN AND CHARACTERISTICS OF THE GROTESQUE}

Flannery O'Connor's two stories "The Lame Shall Enter First" and "Comforts of Home" are typical examples of grotesque short fiction. Therefore, one can reasonably suggest that no assessment of Tomris Uyar's rendering of these stories will be complete unless due consideration is given to the special features of the grotesque and to the way they are reflected in literary works. Actually, before setting out to evaluate the translation of any literary work that falls into the category of grotesque literature, one should first gain some insight into the distinctive features of this type of writing, with special focus on the way characters, incidents, situations and atmosphere depicted in grotesque stories differ from those in other types of stories. Then, based on this notion the grotesque, one can move on to finding out how effectively these special features can be reproduced in translation with due consideration of the receptor language and culture. Accordingly, this section of the article will be devoted to a discussion of the origin and characteristics of the grotesque as a mode of art and literature in its own right, with special emphasis on its implications for the process of translation in particular. Then, an attempt will be made to associate Nida's concept of dynamic equivalence with Tomris Uyar's rendering of the two stories, to be followed by an analysis of the translated texts on the basis of this concept.

The term 'grotesque' has its origin in the fantastic decorations called grottes, found in Roman caves at the end of the $15^{\text {th }}$ century in the Golden House of Nero (Barnard, 1987, p.8). On the walls of these underground chambers were decorations of bizarre human, animal and plant forms commonly known as "grottesco," hence the word grotesque (Rhodes, 1980, p.7). In the period of the Renaissance there was a surge of interest in the grotesque mode of art which was eventually criticized by the leading literary figures of the Neoclassical period (Barnard, 1987, p.8). From the $19^{\text {th }}$ century onwards, however, the term grotesque has been widely used to refer to any kind of literature having connotations of fantastic, ridiculous, extravagant, exaggerated, ugly, distorted, incongruous, freakish, unnatural, uncanny, unorthodox, bizarre, abnormal, as well as anything deviating from the established standards of balance, harmony, and proportion (Cuddon, 1977, p.3). Grotesque literature abounds in strange characters with abnormal attitudes and behavior. As Susan Corey (1997) points out, grotesque is an artistic and literary form that breaks the boundaries of normalcy (p.46).

The grotesque is characterized by the juxtaposition of diametrically opposed concepts such as the tragic and comic, the fearful and the ludicrous, and so on. Due to the paradoxical nature of the grotesque, the reader's response to it is "ambivalent," a curious mixture of laughter and disgust (as cited in Thomson, 1972, p.30). The reader is presented with two aspects of the grotesque, the "comic" and "horrifying (or disgusting)" at the same time (Thomson, 1972, p.31). Hence, one's laughter in the face of the grotesque is far from being "free" or undisturbed; it is an unusual kind of laughter that never brings full relief (ibid., p.32). Grotesque characters and situations shock the audience into an awareness that leads them to perceive the world in a different way. The shock effect thus created at once astonishes and dislocates the audience, confronting them with a disturbing perspective and shaking them off their complacency and habitual way of looking at things. Consequently, the particular impact created by the grotesque is often a sense of 'alienation'; a feeling of estrangement engendered by a situation in which something previously regarded as familiar and trusted becomes suddenly transformed into something strange, disturbing, and precarious. In his seminal work, The Grotesque in Art and Literature, Wolfgang Kayser points out that the grotesque "instills fear of life" by producing an "awareness that the familiar and apparently harmonious world is alienated under the impact of abysmal forces, which break it up and shatter its coherence" (Meindl, 1996, p.15). Kayser further points out that grotesque often appears as an expression of a strange 
and alienated world that is familiar from a perspective which is suddenly rendered strange (presumably, this strangeness may be either comic or terrifying, or both) (Endurance, Yahya and Majeed 2014, p. 43).

\section{THE LANGUAGE OF THE GROTESQUE}

The language of grotesque literature plays an important part in the effect of defamiliarization created through the depiction of grotesque characters and situations. This is a language that jars and unsettles the reader by violating all standards of decorum, thus enhancing the feeling of estrangement engendered by the grotesque. As William F.Axton (cited in Marrs, 1974, p.85) points out, "the grotesque voice is marked by a discrepant use of language to render strange the familiar object-world by discordance and incongruity". The paradoxical nature of the grotesque finds an echo in the language peculiar to the grotesque - "a compound of irreconcilable elements on phonological, morphological, syntactic and semantic language levels" (Buscop, 1999, p.97). By and large, the language of the grotesque is marked by a tendency to violate the norms of conventional language (ibid., p.97). This language pushes the boundaries of acceptability and decency, often disturbing and dislocating the reader not quite accustomed to it. Relating this feature to the 'play' element in the language of the grotesque, Philip Thomson (1972) says,

games with words are ... devious devices of alienation, and at their most radical succeed in producing in the reader a strange sensation - making one suddenly doubt one's comfortable relationship with the language - not unlike the sense of disorientation and confusion associated with the grotesque (p.165).

The language of the grotesque sounds inordinately aggressive, abusive, vulgar, and abject. In specific terms, this is a highly unorthodox language marked by "excessiveness" (Wendel, 2009, pp.16-17) as well as by certain forms of informal speech such as repetition, slang, abuses, curses, oaths, profanities, obscenities, clichés, exaggeration, words with double meaning, ambiguity and distortion through metaphorical (figurative) language, and so on. As Mikhail Bakhtin (1984) points out, the culture of the grotesque body is "a culture of the loud word" (p.182). In fact, the kind of language used in grotesque works gets the reader involved in the incidents and situations depicted, often arousing paradoxical feelings -horror and laughter - at the same time.

\section{THE USE OF IDIOMATIC LANGUAGE IN THE TRANSLATION OF GROTESQUE STORIES}

\section{Idiomatic Translation}

In her renderings of Flannery O'Connor's two stories, "The Lame Shall Enter First" ("Önce Sakatlar Girecek") and "The Comforts of Home" ("Yuvanin Nimetleri"), Tomris Uyar relies heavily on the use of idiomatic language. In fact, Tomris Uyar's method of translating the two stories can be seen as a typical example of how Nida's concept of dynamic equivalence can be applied to the rendering of grotesque works through a receptor-centered approach.

\section{Idioms}

A significant component of colloquial language, idioms can be defined as "a string of words whose meaning is different from the meaning conveyed by the individual words" (Larson, 1984, cited in Al-kadi 2015, p.513). For example, in English, 'giving someone the cold shoulder' is an idiom commonly used in daily life to mean ignoring someone deliberately', while the idiom 'beating around the bush refers to 'a situation in which someone avoids answering a question or getting to the main point'. Similarly, in Turkish, 'Kll kurk yarmak' is a commonly used idiom that means 'paying meticulous attention to something'. Actually, it is rather difficult to figure out the meanings of idioms, since, as Mona Baker (1992) says, "Idioms are frozen patterns of language which allow little or no variation in form and often carry meanings which cannot be deduced from their individual components" (p.63). Since idioms have meanings only at metaphorical (figurative) level, the use of literal translation in the rendering of idiomatic expressions fails to convey the intended meaning. For instance, if the idiom 'to put oneself in someone else's shoes' were to be literally rendered into Turkish as 'kendini başkasının ayakkabılarının içine koymak', this translation would sound absurd to receptors of the target language. Idioms are often used for the purpose of communicating a given message more clearly and emphatically as well as expressing an idea in an original manner so that it will sound more interesting. Idiomatic phrases make it easier for readers to better visualize the scene or object being depicted, and sometimes they serve to add humor to the message being conveyed.

Native speakers commonly use idiomatic language in everyday conversations. In fact, the ability to use and understand idioms is crucial for effective communication in both spoken and written language. An essential part of social and cultural life, idioms enrich language by allowing speakers to express their thoughts and feelings more effectively (Ghafel, Rasakh and Pazhakh 2011, p.160) Commenting on the emotional implications of idiomatic language, Mildred L. Larson (cited in Adelnia and Dastjerdi 2011, p.879) points out that "idiom carries certain emotive connotations not expressed in the other lexical items". Another scholar, John I. Liontas (as cited in Garces, 1997, p.31) argues that idioms constitute a significant part of natural communication in everyday life, and that a knowledge of idiomatic expressions contributes to achieving fluency in conversation. Among the other features of idiomatic language are "social character, spontaneity (freshness) and expressiveness".

Translation of idioms has always been regarded as a serious challenge for translators. Over the course of translation history, a significant body of research has been done on the translation of idioms in the source text and much has been written on the subject, particularly on the strategies that can be employed for the rendering of idioms. While this kind of research has its own value, one cannot fail to acknowledge that little has been done or written in the field about the way idiomatic expressions can be used in receptor language in the translation of non-idiomatic language in the source text, with a view to creating a similar effect on the receptor audience. 
At this point, it should be noted that the features commonly associated with idiomatic language such as familiarity, fluency, expressiveness, spontaneity, and naturalness are also closely linked with receptor-oriented translation since the use of idiomatic expressions contributes much to the overall effect created by the particular discourse of the translated work. Idioms are widely used as a practical way of communicating the content and feelings conveyed by the words and phrases in the original work through a kind of language that sounds familiar to the receptors of target language. Considering the use of idioms in translation "a lively and natural" form of rendering the source text, Peter Newmark (1988) says "Idiomatic translation reproduces the 'message' of the original but tends to distort nuances of meaning by preferring colloquialisms and idioms where these do not exist in the original" (p.41). It is widely agreed that a message communicated through an idiom often creates a stronger impact than a message conveyed by an ordinary word or phrase. With this idea in mind, translators sometimes prefer to use idioms in the rendering of non-idiomatic words or phrases in the source text. However, in the process of translation, there might be a temptation to use idioms unsparingly, which may lead to 'an extremely free' form of translation. Yet, such a strategy, far from enhancing the total impact of the translation, detracts from the overall effect that can be created by a balanced use of idioms in translation.

Closely associated with the tendency to use idiomatic expressions in translation is the notion of compensation, which can simply be defined as an attempt to make up for a loss of effect in the source text. By and large, compensation can be regarded as an outcome of two diametrically opposed trends in translation: (1) A source-text oriented approach which leads to excessive concern about any loss of effect that may occur in translation; (2) A target-oriented approach which centers on creating equal effect through compensation - a strategy adopted as an extension of the concept of dynamic equivalence. In their seminal work, The Theory and Practice of Translation (1982), Nida and Taber draw attention to the importance of compensation, which, they think, has to do with being mindful of any possible loss of effect that may occur in the process of transferring a message in the source text to the target text. The two scholars maintain that the translator needs to make up for this loss of effect by choosing the words or phrases in the receptor language that will best recreate the same effect on the receptor audience. Within this context, Nida and Taber (1982) advocate the idea of using of idiomatic language in the target text as an effective means to compensate for any kind of loss that may occur in translation. Commenting on the significance of employing idioms for the purpose of compensation, Nida and Taber (1982) say:

what one must give up in order to communicate effectively can.... be compensated for, at least in part, by the introduction of fitting idioms. One of the difficulties is that too often translators are not sufficiently sensitive to the possibilities of idiomatic expressions, and hence the end result is a weakening of the figurative force of the translation... (p.106).
From this point of view, compensation through the use of idiomatic language is considered to be an effective method to maintain the expressiveness of the source text. Nida and Taber emphasize the importance of using idiomatic language in translation in receptor-oriented terms, saying "such idiomatic renderings do much to make the translation come alive, for it is by means of such distinctive expressions that the message can speak meaningfully to people in terms of their own lives and behavior" (ibid., p.106).

Another important idea Nida and Taber put forward in their book is concerned with the "adjustments" to be made when dealing with idioms. The two theorists argue that in the process of translation it is possible to minimize any possible loss in semantic content by implementing a number of adjustments. There are three types of adjustments that can be made in the process: "(a) from idioms to non-idioms, (b) from idioms to idioms, and (c) from non-idioms to idioms" (ibid., p.106). More often than not, in the process of rendering the original text the translator has no other choice but to convert an idiom into a non-idiom simply because the idiom in the original text does not have a corresponding equivalent (another idiom) in the receptor language. To cite an example, for the English idiom 'to sit on the fence' there is no idiom in Turkish with exactly the same meaning. Since the literal translation of the idiom as 'çitin üzerinde oturmak' makes absolutely no sense, the best way to translate this idiomatic phrase would be to focus on the semantic content of the original statement rather than trying to literally render each word in the idiom; thus coming up with two possible translations, 'tarafsız olmak' or 'kararsiz kalmak', depending on the context concerned.

In some cases, it might be possible to come up with an idiom in the target language, which proves to be the exact equivalent of the corresponding idiom in the source language, equally capable of creating almost the same semantic and emotional effect (ibid., p.106). For example, the English idiom 'once in a blue moon' can be translated into Turkish with the idiom, 'kırk yılda bir', with exactly the same meaning. On the other hand, when translating the idiom 'to let the cat out of the bag' into Turkish, the literal translation 'kediyi çantadan çıkarmak' would sound awkward and fail to convey the meaning of the original; yet, in the receptor language there is a corresponding idiom that functions as the exact equivalent of the original statement - 'baklayı ağzından çıkarmak', which gives exactly the same meaning. Similarly, the English idiom 'to upset the applecart' can be matched in Turkish by the idiom 'bir çuval inciri berbat etmek', just as the idiomatic phrase 'the last straw' can easily be translated into Turkish with the idiom 'bardağl taşıran son damla'.

Though on rare occasions, sometimes it may turn out that an idiom in the source language, when literally translated, has a corresponding equivalent in the receptor language. To cite an example, the English idiom 'to kill two birds with one stone' can be literally translated into Turkish as 'bir taşla iki kus vurmak' to convey exactly the same message. Likewise, for the idiom in English to kill time, there is a corresponding idiom in Turkish, 'zaman öldürmek', the literal equivalent of the original phrase. 
Still another possibility is that for a non-idiom in the source language an appropriate idiom can be found in the receptor language. If it properly fits into the context, the idiomatic expression used in the translated text not only accurately communicates the source-text message, but also creates a powerful impact on the target audience. Nida and Taber argue that it is possible, even more desirable, to convert a non-idiom into an idiom in translation, and then they cite two examples for this strategy: (1) The word 'faith' can be rendered -as in Tzeltal' - as 'to hang on to God with the heart'; (2) The word 'peace' can be translated as 'sit down in the heart', as in several African languages (ibid., p.106). To illustrate this receptor-oriented approach with several examples, in translating the statement 'He knew the region very well' into Turkish, the use of idiomatic language 'Bölgeyi avucunun içi gibi biliyordu can be preferred to the non-idiomatic rendering of the original sentence as 'Bölgeyi çok iyi biliyordu', though either form of translation accurately conveys the original message. Similarly, the word 'overhear' is translated into Turkish with the idiomatic expression, ' $k u l a k$ misafiri olmak' and the word 'eavesdrop' is rendered into Turkish, with another idiom, 'kulak kabartmak'.

In the examples introduced by Nida \& Taber, it can be noted that sometimes, in the process of transfer, for just one word in the source text a long idiomatic phrase may be used so that an equivalent semantic and emotive effect can be achieved. Alternatively, in certain instances it could be just the other way round. Properly employed, an idiom in the receptor language, which consists of just a word or two, can powerfully communicate a message conveyed by a longer non-idiomatic expression in the original text. For instance, the non-idiomatic phrase 'in a last desperate effort' can be translated into Turkish with a relatively shorter idiomatic expression, 'can havliyle', instead of retaining the non-idiomatic form of the original phrase and rendering it with a longer phrase as 'çaresizlik içinde son bir gayretle', which equally serves to convey the same message and create a similar feeling. Regarding the second case in question, one may assume that, on some occasions, the use of idiomatic language in translation may allow the translator to avoid wordiness. Based on this line of reasoning, one can infer that, the use of an idiom consisting of fewer words or phrases than those in the original text (non-idioms) may, in certain instances, contribute to creating a stronger effect on the target reader, in such a way as to confirm the principle of "Less is more". With all these considerations in mind, one should still recognize that what matters in this kind of translation is not so much the length of the idiomatic phrase used as whether or not this particular idiom can accurately communicate the message and feelings involved in the original word or phrase, with equivalent effect.

In the light of the considerations above, it will be useful, at this point, to cite several examples from the translations of the stories under discussion to find out how consistently Tomris Uyar uses idiomatic equivalents for non-idiomatic words or phrases in the original works. In the examples below are a number of representative idioms selected from "Önce Sakatlar Girecek" and "Yuvanın Nimetleri" intended to illustrate Tomris Uyar's tendency to employ idioms in the translations of the two stories. For each example, an alternative (non-idiomatic) translation of the original phrase has been provided to see the differences between idiomatic and non-idiomatic renderings.

In "The Lame Shall Enter First", the statement 'Sheppard's face was haggard' (466) is translated into Turkish with idiomatic language as 'Suratından düşen bin parçay$d l$ '(160) rather than with the non-idiomatic alternative ' $C a n \imath$ çok sıkkındı.'

Again, in the same story the statement Johnson continued to sit, stock-still' (471) is rendered into Turkish as 'Johnson kılını bile kıpırdatmadı' (166) instead of using standard Turkish, 'Johnson hareket etmeden oturmaya devam etti.'

In the same way, for the statement in the source text ' $h$ is lot would have been easier', (461) which can normally be translated into Turkish as 'hayatı daha kolay olacaktı', the translator uses idiomatic language and renders the sentence into Turkish as 'paçasını kurtarmış olurdu' (154).

Similarly, for the statement 'Norton looked stunned', (454) idiomatic translation has been preferred- 'Norton taş kesilmişti' (146)- rather than the non-idiomatic alternative 'Norton çok şaşırmıştı'.

Tomris Uyar's tendency to use idioms can be seen also in her rendering of "Comforts of Home". For example, the statement 'she doesn't need to supply you with any fancy names' (385), which, in this particular context, has connotations of 'deceiving somebody', could normally be translated into Turkish with a non-idiomatic expression as 'birini kandırmak'. Yet, in this instance the translator prefers to use the idiom 'gözünü boyamak' (112) instead of standard language. While it would be possible to communicate the semantic content of the original story by using non-idiomatic language, there is no question that idiomatic expressions convey the source-text messages more effectively.

Again, in the original story the phrase "with her daredevil charity' (383) has been matched in Turkish by a longer and idiomatic phrase 'gözünü budaktan esirgemeyen yardımseverlik duygusuyla' (110) while an alternative non-idiomatic translation for the source-text phrase could be 'korku nedir bilmeyen bir yardimseverlikle'.

Likewise, the expression in the source text 'when virtue got out of hand with her' (386) has been rendered into Turkish with the idiomatic phrase 'erdemlilikte ipin uсunu kaçırdı ğında' (113) instead of using standard Turkish- 'erdemli olmak konusunda kontrolü kaybettiğinde'.

Finally, in the original text the phrase 'she was infuriated by this' (397) has been matched in Turkish by an idiomatic phrase as 'küplere biniyordu' (126) while an alternative non-idiomatic translation for the same phrase could be 'çok öfkeleniyordu'.

Like many other languages, Turkish abounds in idiomatic phrases which add color and variety to written and spoken expression. The use of idiomatic language in translation is one of the ways of effectively conveying a given message or feeling because it is a language that sounds familiar to receptor audience; it is an integral part of their communication in everyday life. As seen in the examples above, the use of 
idiomatic language contributes to creating in receptor audience the feeling that the translated work sounds like a text originally written in the receptor language. Non-idiomatic translation, on the other hand, barely conveys the semantic content to the target-text reader.

Based on the translator's reliance on the use of idiomatic expressions in the translated stories, one can conclude that this strategy serves two main functions. While on the one hand this method of translation proves to be an effective instrument that becomes instrumental in creating on the receptor audience the impact of the grotesque -an effect similar to the one created by Flannery O'Connor on receptors of the source language; on the other hand, it enables the translator to achieve fluency and naturalness of expression in conveying the message and feelings in the original stories. Both of these functions are in line with Nida's concept of dynamic equivalence, which centers on two fundamental principles in translation: (1) The idea of creating equivalent effect and response in the receptors of the translated text; (2) The notion of achieving fluency and naturalness of expression.

\section{CONCLUSION}

In this article, Tomris Uyar's renderings of two stories by Flannery O'Connor, "The Lame Shall Enter First" and "The Comforts of Home", respectively translated into Turkish with the titles "Önce Sakatlar Girecek" and "Yuvanın Nimetleri" have been studied in the light of Eugene A. Nida's concept of dynamic equivalence, a receptor-centered translation strategy. An analysis of the two translations reveals that, quite in line with Nida's notion of dynamic equivalence, in her rendering of both stories Tomris Uyar follows a receptor-oriented approach, clearly manifested in her tendency to use various kinds of idioms for the purpose of bringing the semantic and emotive content of the source-text closer to target-text reader. As seen in the extracts above, the translator uses various forms of idioms in Turkish to be able to effectively portray in the receptor language the grotesque characters, incidents, and situations, as well as the setting and atmosphere depicted in the stories. The way in which the extracts selected from the original stories have been translated clearly illustrate the extent to which the emotive impact of the grotesque in the original stories can be reproduced through the use of idioms, which are an integral part of the Turkish spoken in everyday life. The idioms used in the translation of the two stories are by no means limited to the ones presented in this study, but, for practical purposes, only the most representative ones have been selected. Yet, the extracts taken from the translated stories should be enough to show that Tomris Uyar's rendering of both stories is marked by a receptor-oriented approach that gives precedence to the norms of target language and culture.

In her translation of the two stories, Tomris Uyar adopts a domesticating strategy in the use of receptor language with a view to creating a similar response and equivalent effect on target audience as well as achieving a natural and fluent style of expression. As Giuseppe Palumbo (2009) puts it, "Domestication is a global strategy aimed at producing a transparent, fluent style in the target language" (p.38). While some translation scholars like Lawrence Venuti criticize domestication on the grounds that it tends to subordinate the source-text norms to those of the target language, Tomris Uyar implements this strategy to make receptor audience feel as if the stories they are reading were originally written in their own language. As such, the strategy of domestication becomes instrumental in making the source text more accessible to the target-text reader. This receptor-centered approach proves to be all the more relevant because grotesque stories lend themselves well to the use of domestication as a translation strategy. As Palumbo points out, "As a mode of translation, domestication entails translating in a transparent form felt as capable of giving access to the source-text author's precise meaning" (ibid., pp.38-39). To the same effect, Eugene A. Nida (1964) suggests that it is possible to communicate the semantic and spiritual (emotive) content of the source text through a receptor-oriented approach, which lies in the core of his concept of dynamic equivalence. A translation guided by the principle of dynamic equivalence "tries to relate the receptor to modes of behavior relevant within the context of his own culture" (p.159). Contrary to what is often assumed, this strategy does not lead to a loss of effect in transferring the semantic and emotive content of the source text because, as Nida argues, there are adjustments that can be made with the tools of compensation; namely, with colloquialisms in general, and idioms in particular. Viewed from this perspective, the method of translation implemented in the two stories suggests that the use of idiomatic language as a domesticating strategy, far from leading to "an ethnocentric reduction of the source-text to target language values" as Venuti argues, can inversely prove to be an effective means to convey the semantic content of the source text and create the impact intended by the author (Palumbo, 2009, p.39).

Tomris Uyar's method of rendering the two stories reveals that she is highly keen on letting target-text readers vividly visualize the incidents and scenes in the stories by using a kind of language that sounds familiar to them, the language they use in their day-to-day lives. The translator has a marked tendency to use idioms for non-idioms in translation, which can be viewed as part of a domesticating strategy, a receptor-oriented approach, designed to make target-text readers vividly picture what is happening in these stories as if they were part of all that is being depicted. As the characters in the stories speak the very language being spoken in the everyday lives of target-text readers, it becomes much easier for receptor audience to understand the characters' feelings, experiences as depicted in these stories. Target-text readers become mentally and emotionally involved in the stories, feeling as if they were part of the grotesque world being depicted, physically experiencing the incidents, rather than passively viewing all that is happening from a certain distance.

\section{END NOTE}

1. A Mayan language spoken in southeastern Mexico. 


\section{REFERENCES}

Adelnia, A., \& Dastjerdi, H. V. (2011). Translation of Idioms: A Hard Task for the Translator. Theory and Practice in Language Studies 1 (7), 879-883. doi:10.4304/ tpls.1.7.879-883

Al-kadi, A. M. T. (2015). Towards Idiomatic Competence of Yemeni EFL Undergraduates. Journal of Language Teaching and Research 6 (3), 513-523. doi: http://dx. doi.org/10.17507/jltr.0603.06

Baker, M. (1992). In Other Words: A Coursebook on Translation. London and New York: Routledge.

Bakhtin, M. (1984). Rabelais and His World (H. Iswolsky, Trans.). Bloomington: Indiana University.

Barnard, M. E. (1987). The Myth of Apollo and Daphne from Ovid to Quevedo: Love, Agon, and the Grotesque. Durham: Duke University.

Bassnet, S. (2002). Translation Studies. London and New York: Routledge.

Buscop, J. (1999). The Grammar of the Grotesque: A Linguistic Reading Mode. South African Journal of Linguistics, 17: 2-3, 97-109. https://doi.org/10.1080/10118 063.1999.9724528

Corey, S. (1997). The Religious Dimensions of the Grotesque in Literature: Toni Morrison's Beloved. In J. L. Adams, W. Yates \& R. P. Warren (Eds.), The Grotesque in Art and Literature: Theological Reflections (p.46). Grand Rapids, Mich.: W.B. Eerdmans.

Cuddon, J. A. (1977). A Dictionary of Literary Terms. N.Y.: Doubleday.

De Jonge, H. J. (2016). Erasmus's Translation of the New Testament: Aim and Method. The Bible Translator 67 (1), 29-41. https://doi.org/10.1177/2051677016628243

Endurance, A., Yahya, W. R. B. W., \& Majeed, A. A. (2014). The Grotesque Elements in Poe's "Black Cat" and Scudder's "The White Cat. International Journal of Comparative Literature \& Translation Studies. 2 (2): 42-46. doi:10.7575/aiac.ijclts.v.2n.2p.42

Garces, C. V. (1997). Contrastive Idiomatology Equivalence and Translatability of English and Spanish Idioms. $\mathrm{Pa}$ pers and Studies in Contrastive Linguistics, 29-38.

Ghafel, B., Rasekh, A. E., \& Pazhakh, A. (2011). Idiomatic Expressions of the Sewing Frame in English and their Persian Counterparts: Nida's Dynamic Equivalence Theory in Focus. International Education Studies 4 (2), 160-168. doi:10.5539/ies.v4n2p160

House, J. (2002). Universality versus Culture Specificity in Translation. In A. Riccardi (Ed.), Translation Studies Perspectives on an Emerging Discipline (pp.89-98). Cambridge University.

House, J. (2015). Translation Quality Assessment Past and Present. New York: Routledge.

Kristal, E. (2002). Invisible Work: Borges and Translation. Nashville: Vanderbilt University.
Levý, J. (2011). The Art of Translation (P. Corness, Trans.). In Z. Jettmarová (Ed.), Amsterdam/Philadelphia: John Benjamins.

Marrs, B. G. (1974). Joseph Conrad's The Secret Agent and the Grotesque. (Master thesis). University of British, Columbia.

Meindl, D. (1996). American Fiction and the Metaphysics of the Grotesque. Columbia: University of Missouri.

Munday, J. (2008). Introducing Translation Studies Theories and Applications. $2^{\text {nd }}$ ed. New York: Taylor \& Francis.

Newmark, P. (1988). A Textbook of Translation. New York: Prentice -Hall International.

Nida, E. A. (1964). Toward A Science of Translating With Special Reference to Principles and Procedures Involved in Bible Translating. Leiden: E. J. Brill.

Nida, E. A. \& Taber, C. R. (1982). The Theory and Practice of Translation. Leiden: E. J. Brill.

O'Connor, F. (1971). The Complete Stories. The United States of America: Farrar, Straus and Giroux.

Palumbo, G. (2009). Key Terms in Translation Studies. London and New York: Continuum International.

Pym, A. (2010). Exploring Translation Theories. London and New York: Routledge.

Rhodes, N. (1980). Elizabethan Grotesque. 18 ${ }^{\text {th }}$ ed. London: Routledge \& Kegan Paul.

Shakernia, S. (2013). Study of Nida's (formal and dynamic equivalence) and Newmark's (semantic and communicative translation) Translating Theories on Two Short Stories. Merit Research Journal of Education and Review 2(1), 001-007.

The Reverend Eugene Nida. Retrieved September, 11, 2018 from https:/www.telegraph.co.uk/news/8736036/ The-Reverend-Eugene Nida.html

Thomson, P. (1972). The Grotesque. London: Methuen and Co.

Uyar, T. (2010). Her Çıkışın Bir Inişi Vardır (Flannery O’connor). (Çevirenler: Tomris Uyar, Nazım Dikbaş, Fatih Özgüven). İstanbul: Metis.

Venuti, L. ed. (2000). The Translation Studies Reader. London: Routledge.

Venuti, L. (2001). Strategies of Translation. In M. Baker (Ed.), Routledge Encyclopedia of Translation Studies (pp.240-244). London \& New York: Routledge.

Wang, M. (2014). A Study on Semantic and Communicative Translation of Magical Things in Harry Potter. Studies in Literature and Language - CSCanada 8 (2), 26-31. doi: $10.3968 / 4353$

Weissbort, D. \& Eysteinsson, A. (Eds.). (2006). Translation- Theory and Practice: A Historical Reader. Oxford: Oxford University.

Wendel, D. (2009). Gender, Genre and the Grotesque: Literary Subversions of Renaissance Patriarchy. The Knox College Online Journal of Literary Criticism 12 (1), 1-22. 